\title{
NIKE VS ADIDAS - KÖRNYEZETVÉDELMI ERŐFESZÍTÉSEK EREDMÉNYEI
}

\author{
Ráthonyi-Ódor Kinga - Bácsné Bába Éva - Ráthonyi Gergely
}

\section{Összefoglalás}

A "felelös magatartás" kérdéskörével foglalkozó kutatások alapján elmondható, hogy a fogalom tisztázása nem egyszerü feladat, hiszen a szakirodalom sem egységes. Az eltérö meghatározások hasonlóak abban a tekintetben, hogy az üzletmenetben meg kell teremtödnie egy egészséges és fenntartható egyensúlynak a gazdasági érdekek, a társadalmi elvárások és a környezeti értékek figyelembe vétele között.

A felelös magatartás megjelenése a gazdasági élet különbözö szektoraiban, eltérö tevékenységek révén valósulhat meg. Az egyik ilyen, napjainkban egyre népszerübb kutatási terület, a sportszektor felelós magatartásának vizsgálata.

Vitathatatlan, hogy minden sporttal kapcsolatos tevékenység hatással van a természetes környezetre, hiszen természeti eröforrásokat használ. A területek kisajátítása, a biodiverzitásra gyakorolt hatás, az ivóviz minöségü vizek felhasználása, a hulladék kibocsátása, a vendéglátás, a sportlétesitmények épitése és müködtetés, valamint a sporteszközök gyártása és eladása megsokszorozza azokat a megoldásra, zölditésre váró feladatokat, melyeken segithet a felelös magatartás.

Jelen tanulmány célja, hogy vezetö piaci pozícióban lévö multinacionális sportszer-és sportruházat gyártó vállalatok - Nike, Adidas - tevékenységébe integrált környezetbarát megoldásait ismertesse.

Kulcsszavak: sportszer-és sportruházat gyártó vállalatok, környezetvédelem, felelös magatartás

JEL: M14

DOI: 10.33032/acr.2019.9.2.133 


\title{
NIKE VS ADIDAS - RESULTS OF ENVIRONMENTAL EFFORTS
}

\begin{abstract}
According to study, dealing with "responsible behaviour", we can say that clarification of this concept is not easy, because literatures are not integrated. The various definitions are common in the respect that a healthy and sustainable balance should be created between economic interests, social expectations and environmental limits in the course of business.

The socially responsible approach of a firm can be manifested through its actions One of these, increasingly popular research area is the study of responsible behavior in the sport sector.

Undoubted, that all sports use natural resources in some measure and have an impact on natural environment. Expropriation of territory, affect of biodiversity, use of clean water, waste emission, building and operation of sports facilities, cuttering, producing and disposal of sports equipment multiply are those tasks, waiting for greening, that can and should be helped by responsible behaviour.

The aim of our study is to present top sporting goods manufacturers' - Nike, Adidas environmentally friendly solution in the course of their manufacturer activity.
\end{abstract}

Keywords: sporting goods manufacturers, environmental protection, responsible behaviour

JEL: M14 


\section{Bevezetés}

A „felelös magatartás” kérdéskörével foglalkozó kutatások alapján elmondható, hogy a fogalom tisztázása nem egyszerủ feladat, hiszen a szakirodalom sem egységes e tekintetben. Az eltérő meghatározások hasonlóak abban a tekintetben, hogy az üzletmenetben meg kell teremtődnie egy egészséges és fenntartható egyensúlynak a gazdasági érdekek, a társadalmi elvárások és a környezeti értékek figyelembe vétele között.

A felelős magatartás megjelenése a gazdasági élet különböző szektoraiban, eltérő tevékenységek révén valósulhat meg. Az egyik ilyen, napjainkban egyre népszerűbb kutatási terület, a sportszektor felelős magatartásának vizsgálata.

A sportszektor felelös magatartásának egyik aspektusa a sport és a környezetvédelem kérdéskörének vizsgálata, mellyel foglalkozó tudományos munkák száma jelentősen megnőtt az elmúlt 15 évben (Trendafilova et al., 2014).

A fenntartható fejlődés elérésének egyik stratégiai elképzelése a gazdaság zöldítése (Tóthné - Roncz, 2016), mely alól a sport sem lehet kivétel.

Vitathatatlan, hogy minden sporttal kapcsolatos tevékenység hatással van a természetes környezetre, hiszen természeti erőforrásokat használ. A területek kisajátítása, a biodiverzitásra gyakorolt hatás, az ivóvíz minőségű vizek felhasználása, a hulladék kibocsátása, a vendéglátás, a sportlétesítmények építése és működtetés, a sporthelyszínek közötti ingázás, valamint a sporteszközök gyártása és eladása megsokszorozza azokat a megoldásra/zöldítésre váró feladatokat, melyeken segíthet a felelős magatartás (Brar - Pathak, 2016; Shiply, 2018).

A sport igen népszerủ a modern társadalmakban (Deng - Zhou, 2017), egyre több sportszervezet/klub, sportszergyártó cég integrál környezeti elemeket üzleti stratégiájukba (Moghaddam et al., 2018), ezáltal a sport a fenntartható fejlődés egyik alapvető ösztönzője lehet (Giulianotti et al., 2018).

Shipley (2018) szerint, ha a sportot és üzleti környezetét zöldebbé akarjuk tenni, az alábbi intézkedések szükségesek:

- szervezeti formában valósuljon meg a környezetvédelem, természetvédelem támogatása;

- a fenntartható fejlődés megvalósulását szolgáló irányvonalak lehatárolása;

- a természettel és a környezettel összhangban lévő sporttevékenységek, sportprogramok kialakítása;

- a sporttal összefüggő infrastruktúra környezetbarát kialakítása;

- állami szerepvállalás e területen;

- környezetvédelmi szempontok integrálása klubok, szövetségek, sportvállalatok müködésébe; 
A fenti felsorolás alapján jól látható, hogy a sporttársadalom széleskörű összefogására van szükség ahhoz, hogy a környezetbarát megoldások sportba történő integrációja hatékony és eredményes lehessen.

Jelen tanulmány célja, hogy vezető piaci pozícióban lévő multinacionális sportszer- és sportruházat gyártó vállalatok - Nike, Adidas - tevékenységébe integrált környezetbarát megoldásait ismertesse.

\section{Anyag és módszer}

A sportszer- és sportruházat gyártó vállalatok (Nike, Adidas) tevékenysége során alkalmazott környezetbarát megoldások feltárásakor másodlagos adatforráson nyugvó dokumentumelemzést alkalmaztunk. Az elmúlt években az interneten közzétett jelentéseket, esettanulmányokat, jó-gyakorlatokat vizsgálva gyüjtöttünk példákat arra, hogy az egyes területeken (pl.: energiafelhasználás, vízfelhasználás, hulladék-kibocsátás, megújuló erőforrások használata) milyen megoldások születtek tevékenységük zöldítése során.

\section{Eredmények}

\section{Nike}

A Nike a világ vezető sportszer- és sportruházat gyártó vállalata, mely az elmúlt 10 évben megduplázta éves jövedelmét. 2010 óta folyamatosan nőtt a foglalkoztatottak száma, 2017-ben hozzávetőlegesen 65000 fö dolgozott a cégnél (NIKE, 2018).

Egy, a teljes gazdasági tevékenységükre kiterjedő felmérésnek köszönhetően, tisztábban vannak azzal, hogy az alapanyag felhasználás és a gyártás az a két terület, melyek hatása leginkább meghatározó, és környezetvédelmi szempontból a legnagyobb odafigyelést és fejlesztést igénylő. Évente kb. 900 millió terméket gyártanak, melyekhez az alapanyagot mintegy 1500 beszállítótól kapják. Az alapanyag előállításához kapcsolódik a teljes energiafogyasztás 21\%-a, a teljes vízfelhasználás 73\%-a, és az üvegházhatású gázok kibocsátásának 33\%-a. Amennyiben a feldolgozási folyamatokat is figyelembe vesszük, ezek az arányok 54\% - 83\% - 56\%-ra növekednek (NIKE, 2013).

Annak érdekében, hogy tevékenységük környezeti hatásait, a benne rejlő veszélyeket és lehetőséget még jobban átlássák, több pillérre épülő környezeti programot dolgoztak ki az elmúlt években:

1. $\mathrm{CO}_{2}$ kibocsátás 
A vállalat célul tűzte ki, hogy a 2011-es kibocsátási szinthez képest 20\%-kal csökkenti a $\mathrm{CO}_{2}$ kibocsátást 2015 végéig. A 2013-as év végéig 13\%-os csökkentést tudtak megvalósítani, az alábbiaknak köszönhetően:

- A partnerek 41\%-a teljesítette a Nike Energia és Karbon Programjában megfogalmazott elvárásokat;

- Növelték a megújuló energiaforrások használatát az irodákban, az üzletekben és a két legnagyobb logisztikai központjukban. Pl.: A Belgiumban megtalálható Európát kiszolgáló központban, a napelem rendszeren kívül 6 szélturbina is található, melyek összesen közel 20 millió $\mathrm{kWh}$ energiát termelnek (Nike, 2013).

A 2016/17-es időszak eredményeit összegezve elmondható, hogy a lábbelik és egyéb termékeknél, a termékegységre jutó karbonlábnyomot 2,5\%-kal sikerült csökkenteniük a 2015-ös év teljesítményéhez képest, majd a 2018/19-es időszakban ez az arány tovább emelkedett 7,5\%-ra (Nike, 2019). Célul tűzték ki, hogy 2020-ig ez az arány elérje a 10\%-ot. A csökkenés köszönhető pl.: az alacsony környezeti hatású alapanyagoknak, a megújuló erőforrások növekvő arányának, az ellátási lánc energiahatékonyságának a növelésének. Olvashatunk továbbá arról is, hogy tisztában vannak a légi közlekedés környezetterhelő hatásával, azonban sok esetben mégis ezt választják a szállítási idő csökkentése érdekében (Nike, 2018).

2. Mérgező anyagok kibocsátása

A '90-es évek végén, több multinacionális céghez hasonlóan, a Nike-ot is számos támadás érte a felhasznált vegyszerekkel kapcsolatban. 2001-ben összeállították az általuk használt vegyszerek listáját és azok hatásait, illetve, hogy az egyes vegyszereknek milyen környezetbarátabb és az egészségre kevésbé ártalmas helyettesítői vannak. Ezt követően célul tűzték ki, hogy minimalizálják az összetevők hatását a termékek teljes életciklusa során. Terveik között szerepel, hogy 2020-ig nullára redukálják az egyes termékeknél használt káros anyagok mennyiségét. Céljaik elérése érdekében egyrészt tréningeket szerveztek a kémiai anyagok hatásaival, illetve azok környezetbarát vegyszerekkel történő helyettesítésével kapcsolatban, másrészt több nagyvállalattal együttmüködve kidolgoztak egy olyan listát (Product Restricted Substance List, 2017-től lépett érvénybe), mely az alkalmazható/szigorítással használható/betiltott vegyszerek körét tartalmazza. Céljaik között szerepel továbbá, hogy 2020-ig termékeik 100\%-a megfeleljen a 2017-ben bevezetett szigorított listának (Nike, 2018). 2018-ban ez az arány 98\% volt, míg 2019-ben 99\% (Nike, 2019). 


\section{Vízfelhasználás}

2011-ben célul tűzte ki a vállalat, hogy termékegységenként 15\%-kal csökkentik a vízfelhasználás arányát 2015 végéig. 2013-ban már jelentős eredményeket értek el, hiszen a sportcipők esetében 26\%-kal, a sporteszközök esetében 13\%-kal sikerült csökkenteni a felhasznált vízmennyiséget. 2013-ban a cég közel 800 partnere csatlakozott a Nike vízvédelmi programjához, melynek keretén belül önbevalláson alapuló jelentésekben tették közzé a cég termékeihez gyártott alapanyagok vízszükségletét (Ráthonyi-Ódor, 2015).

2016-ban kidolgoztak egy „Minimális Vízfelhasználás” programot, mely keretén belül az egyes gyáraknak, partnereknek próbáltak segítséget nyújtani a vízfelhasználás csökkentésével, szennyvíz kezelésével kapcsolatban. A program bevezetése óta a gyártási folyamatok során keletkezett szennyvíz 40\%-a kezelés után újra felhasználásra kerül, továbbá célul tüzték ki, hogy 2020-ig 20\%-kal csökkentik 1 kg pamut végső megmunkálásához szükséges ivóvíz minőségü vízfelhasználás mértékét. 2017-ig 7,4\%-os csökkenést tudtak elérni (Nike, 2018).

\section{Hulladékcsökkentés}

A vállalat a hulladékcsökkentésükkel kapcsolatban az alábbi intézkedéseket emelte ki a vizsgált jelentésekben (I1, Nike, 2013, 2018, 2019):

- 2011-2015 közötti idöszakban vállalták, hogy 10\%-kal csökkentik a termékek elóállítása során keletkezett hulladékok arányát és a cipős dobozok súlyát. 2013ban 8,6\%-kal sikerült csökkenteni a hulladékok mértékét, míg a cipös doboz súlyát csupán 3\%-kal.

- 2016-ban a NIKE Free RN Flyknit futócipő kialakításával, egy hagyományos futócipő elóállításához képest, $60 \%$-kal sikerült csökkenteni a hulladéktermelést. A termelési osztályon tovább dolgoznak azon, hogy 2020-ig a hulladékcsökkentés aránya a lábbeliknél elérje a 96\%-ot, míg a többi terméknél a 97\%-ot.

- A cipők gyártása során a keletkezett hulladékok 85\%-át már sikerült újrahasznosítaniuk 2013-ban, majd ez az arány 96\%-ra nőtt 2017-ben és 99,9\% lett 2019-ben.

- Évente több millió cipős dobozt gyártanak, melyek 100\%-ban újrahasznosított alapanyagból készülnek 2013 óta.

- 1990 óta, újrahasznosítási programjuknak köszönhetően, több mint 30 millió pár használt cipőt tudtak újrahasznosítani.

- 2017-ben sikerült megvalósítani, hogy az elosztó központban és a központi irodában keletkezett hulladék 8\%-a került csak a hulladéktárolóba, míg a kínai, indonéziai és indiai gyárakban keletkezett hulladék 0\%-a. Egy része újra használatba került, egy részét újrahasznosították, míg egy kisebb mennyiségből energiát állítottak elő. 


\section{Energia}

A cég egy felvásárlási megállapodást írt alá, mely segítségével 2019-ben Észak-Amerikában megvalósulhat, hogy energiaszükségletüket 100\%-ban megújuló erőforrásból fedezik, és a tervek szerint 2025-ig ezt globálisan is kiterjesztik a saját és kiegészítő szolgáltatásaik esetében.

A lábbelik elóállításával foglalkozó gyárakban a régi gőzkazánok cseréjével 1520\%-os energia megtakarítást értek el 2016/17-ben.

Míg 2015-ben a megújuló erőforrások aránya 14\% volt, 2017-re 9\%-os növekedést (23\%) tudtak elérni (Nike, 2018), 2025-re pedig kizárólag megújuló erőforrásokat szeretnének használni (Nike, 2019).

Célul tüzték ki, hogy 2020-ig:

- a termékegységre jutó energiafogyasztás 25\%-kal csökkenjen, 2017-ben ez az arány 4,7\% volt.

- $1 \mathrm{~kg}$ pamut festéséhez és végső megmunkálásához szükséges energiafogyasztás 35\%-kal csökkenjen, 2017-ben ez az arány 14,95\% volt (Nike, 2018), majd az ezt követő 1 évben nem változott (Nike, 2019).

Annak érdekében, hogy növelni tudják a megújuló erőforrások használatának arányát, a gyárak tetejére fotovoltaikus rendszereket telepítettek és elötérbe helyezték a biomassza használatát.

2016-ban adták át az Európai Logisztikai Központ legújabb épületét, mely LEED Gold minősítést szerzett. Nagy figyelmet fordítottak arra, hogy a természetes fényviszonyokat minél jobban kihasználják és automatikus vezérlésű LED izzós világítást alakítottak ki. A zöld területeken a „fünyírás” bárányok segítségével valósul meg.

Az elmúlt években az alábbi sikeres környezetvédelmi intézkedések kerültek még megvalósításra a cégnél:

- 2012-ben vezette be a Nike a „Drydye” textilfestési eljárást, mely során víz helyett nagy nyomású sürített szén-dioxiddal oszlatják szét a festéket a textileken. A korábbi hagyományos eljáráshoz képest pólóként 30 liter vizet, éves szinten közel 6 milliárd liter vizet tudnak megspórolni. Az új eljárási folyamat 50\%-kal gyorsabb a hagyományos festéshez képest, 63\%-kal kevesebb energiát és kb. 50\%-kal kevesebb kemikáliát igényel. Az eljárás végén a gáz újra felhasználható állapotba kerül, így az nem kerül ki a légkörbe (Elks, 2013). Az eljárás 2014-ben „magas környezeti és fenntarthatósági értéket képviselő technológia” díjban részesült.

- A cég néhány éve csatlakozott a „jobb pamut” kezdeményezéshez (Better Cotton Initiative), mely a fenntartható pamuttermelés megvalósítására koncentrál. Ennek a holisztikus megközelítésen alapuló termelésnek a célja, hogy 
pl.: a termelés során csökkentsék a peszticidek használatát, gazdaságos legyen a vízfelhasználás, alkalmazzanak vetésforgót és, hogy érvényesüljenek a fair trade alapelvei. (A termelők nemcsak egy minimális árat kapnak, mely magába foglalja a fenntartható termelés költségeit, hanem egy Fair trade Premium-ot is, továbbá tisztességes munkakörülmények között dolgoznak.) Az elmúlt években bebizonyosodott, hogy a vízhasználat 20\%-kal, míg a rovarölő szerek használata 67\%-kal volt csökkenthető a fenntartható pamuttermelés megvalósításával, melynek köszönhetően a farmerek jövedelmezőségi mutatói javultak. A hosszú távú cél, hogy 2020-ig 5 millió farmer csatlakozzon a kezdeményezéshez, akik összesen a világ teljes pamuttermelésének 30\%-át (8,2 milliárd kg pamut) tudnák biztosítani (Ráthonyi-Ódor, 2015). A Nike 2019-es jelentése szerint, az általuk használt pamutnak már 50\%-a BCI, 8\%-a organikus gazdálkodásból és kevesebb, mint 1\%-a újrahasznosított pamutból származik.

- A 2018-ban megjelent jelentés szerint a fenntartható pamuttermelésnek köszönhetően, 24 milliárd liter víz, és $85000 \mathrm{~kg}$ rovarölő szer használatát spórolták meg. 1 év alatt ezek az értékek tovább növekedtek, mára már 32 milliárd liter víz, és $111000 \mathrm{~kg}$ rovarölő szer használatát tudták mellőzni (Nike, 2019).

- A '90-es évektől foglalkoznak a lábbelik gyártásánál használt gyanta környezetbarátabbá tételével. 2004-ben a termékek 3\%-nál, 2017-ben 98\%-nál használtak környezetbarát gyantát.

- 2010 óta több mint 6,4 milliárd műanyag flakont használtak fel újrahasznosított poliészter gyártásához (Nike, 2019).

- A legújabb jelentés szerint (Nike, 2019) a Nike termékek 75\%-a eltérő mértékben ugyan, de tartalmazott újrahasznosított alapanyagot. A felsőruházat 29,5\%-a (10,1\%-os növekedés 2015-höz képest), a lábbelik 32,5\%-a (1,5\%os növekedés 2015-höz képest).

\section{Adidas}

Az Adidas Európában az első, míg a világon a második legnagyobb sportszer- és sportruházat gyártó vállalat. 160 országban több mint 50000 föt foglalkoztatnak, az éves szinten előállított termékek száma meghaladja a 650 milliót.

A cég által kiadott fenntarthatósági/éves jelentések (Adidas 2013, 2014, 2017, 2018) négy pillérre (bolygó, társadalom, termékek, partnerek) épülve mutatják be a fenntarthatósági intézkedéseket, melyek közül kettőben (termékek, bolygó) konkrét környezetvédelmi tevékenységekről is olvashatunk. 
Teljes tevékenységük környezeti hatásának (Adidas, 2018):

- 42\%-a az üvegházhatású gázok kibocsátásához kötethető, mely 54\%-át a beszállítóik tevékenysége (elsősorban alapanyag elöállítása) okozza.

- 31\%-a légszennyezéshez köthető, ezt részben a szintetikus anyagok előállításával, részben a fosszilis energiahordozók elégetésével magyarázzák.

- 15\%-a a vízfogyasztáshoz köthető, melynek túlnyomó része az alapanyag elöállításhoz, termeléshez kapcsolódik.

- 6-6\%-a pedig a vízszennyezéshez és a területhasználathoz köthető.

\section{Termékek}

\section{Vízfelhasználás}

A vállalat, a Nike-hoz hasonlóan, 2012-ben vezette be a DryDye textilfestési eljárást. 2016-ban már nem csak a ruhák, hanem a sporteszközök festése is ezzel az eljárással valósult meg. 2014 óta 22\%-kal sikerült csökkenteni a vízfelhasználás mértékét az alapanyagoknál (121 liter/kg-ról 95 liter/kg-ra).

2016-ban 4 partner céggel kezdődött együttmüködés a vízcsökkentés érdekében. A cégek adatokat bocsájtanak az Adidas rendelkezésére, melyek ismeretében igyekeznek megoldást biztosítani a vízcsökkentés megvalósítására. A vízmegtakarítás területén 2020-ig az alábbi célokat tűzék ki (Adidas, 2017):

- kulcsfontosságú beszállítóiknál vízmegtakarítási programok bevezetésének ösztönzése, hogy 20\%-kal kevesebb vizet használjanak (2016 végéig ez az arány $11 \%$ volt);

- 50\%-os vízmegtakarítás a ruházati alapanyagok beszállítóinál;

- irodaházakban az 1 före jutó vízfelhasználás mértékének 35\%-kal történő csökkentése (2016 végéig ez az arány 23\% volt).

2. Ökológiai lábnyom csökkentése informatikai eszközök segítségével

Az elmúlt években az Adidas nagy hangsúlyt fektetett a tájékoztatók virtuális megjelenítésére, melynek köszönhetően 2 év alatt 1,5 millió példánnyal csökkentették a nyomtatott brosúrák számát. Ennek köszönhetően csökkent az energiafelhasználás, a vízfelhasználás és az üvegházhatású gázok kibocsátása is. Ezek a csökkentések nem csak a nyomtatás, hanem a papír alapú termékek szállításának mérsékelésével is magyarázhatóak (Ráthonyi-Ódor, 2015).

A 2014-ben kiadott jelentésben is megemlítik, hogy az eladásnál a képeket digitalizálták, illetve, hogy a gyártási folyamatoknál is ezt a módszer használják. A számítógép által készített 3D képek segítségével tervezik meg a következő kollekciókat. 
Korábban ahhoz, hogy elkészítsenek egy terméket, szükséges volt először megalkotni egy prototípust, most azonban már nincs erre szükség. A virtuális képeknek köszönhetően 2012-2015 között 2 millióval kevesebb papír alapú mintát, 1,3 millióval kevesebb felszerelési mintát és 600000 kevesebb lábbeli mintát bocsátottak ki. 2013-hoz képest 27\%-kal csökkentették a kibocsátott minták számát, melynek köszönhetően időt és nyersanyagot is megspóroltak, valamint csökkentették a szénkibocsátás mértékét (Adidas, 2014).

\section{Hulladékcsökkentés}

A termelés során keletkezett hulladékok minimalizálását elsősorban a sportcipők, és egyéb sportruházati termékek előállításánál tűzték ki célul. Ennek érdekében arra törekedtek, hogy termékeik újrahasznosíthatóak legyenek, újrahasznosított alapanyagból (újrahasznosított poliészter) készüljenek, minél kevesebb összetevőből álljanak és növeljék a mintahatékonyságot. Az összetevők számának csökkentésére azért volt szükség, mert minél több darabból áll egy termék, annál több hulladék képződik a varrás során, és ugyanez elmondható a minták túlzott használatával kapcsolatban is. Minél többféle minta kerül alkalmazásra, az összeillesztésnél, annál nagyobb veszteséggel lehet számolni. A sportcipők gyártásánál 60\%-kal sikerült csökkenteniük az összetevők arányát, és 95\%-ra növelték a mintahatékonyságot. Az egyéb sportruházati termékeknél is megvalósult a 95\%-os mintahatékonyság, a keletkezett hulladékot pedig plüss mackók kitömésére használták fel (Adidas, 2013).

2012-ben az Adidas is bevezette, hogy bármilyen márkájú használt cipőt vissza lehetett vinni a boltokba. Ezek után, az adott boltban történő vásárlás során kedvezményesen lehetett hozzájutni a cipőkhöz. Brazíliában és Kanadában már sikeresen müködik ez a kezdeményezés. Jelenleg Angliában és Nyugat-Európában dolgoznak a program bevezetésén.

2020-ig az alábbi teljesítendő célokat fogalmazták meg (Adidas, 2017):

- kulcsfontosságú partnereiknél 20\%-os hulladékcsökkentés (2016 végéig a partnerek 39\%-a csatlakozott a programhoz);

- $\quad$ saját tevékenységükből adódóan, hulladéklerakóba kerülő szemét mennyiségének 50\%-os csökkentése;

- alkalmazottak papírhasználatának 75\%-os csökkentése (2008 óta 49\%-os csökkentést értek el).

\section{Környezetbarát alapanyagok}

Az Adidasnak már 2013-ban sikerült túlteljesítenie korábbi célkitűzését 11\%-kal, miszerint a felhasznált pamut mennyiségének 15\%-a BCI legyen. A 2017-es jelentésben arról olvashatunk, hogy termékeik elóállítása során már 68\%-ban fenntartható pamutot 
használtak. Fő céljuk az volt, hogy 2018-ig minden termékkategóriájukban 100\% legyen ez az arány, mely teljesítéséről már olvashatunk a 2019-es jelentésben (Adidas, 2018).

Az újrahasznosított poliészter használata is megvalósult a vállalatnál. Míg a hagyományos poliészter kőolajból készül, addig az újrahasznosított poliészter újrahasznosított anyagokból áll: újrahasznosított mủanyag flakonokból, használt ruhákból. 2024-ig célul tűzték ki, hogy minden Adidas és Reebok terméküknél 100\%-ban újrahasznosított poliésztert használjanak (Adidas, 2018). 2014-ben a német nemzeti melegítők is újrahasznosított poliészterből készült, illetve a Real Madrid és a Bayern München mezei is ilyen alapanyagból kerültek előállításra (Adidas, 2014).

2014-ben vezették be No Dye programjukat, mely keretén belül az anyagokat természetes színükkel használták fel, 5 termékkategóriában. 150000 termék esetében alkalmazták ezt az eljárást. A cipőket zöld technológiával készítették, szem előtt tartva a környezeti hatásokat. A gyártás során semmilyen kémiai anyagot vagy pigment anyagot nem használtak (Liam, 2015).

A nem újrahasznosított műanyag használatát csökkenteni szeretnék az alábbi intézkedések segítségével: műanyag bevásárló táskák megszűntetése a boltokban (így évente 70 millió táskát helyettesítenek papír táskával), újrahasznosított poliészter használata a termékeknél, új beszállítók felkutatása (Adidas, 2017).

$\mathrm{Az}$ „óceánból kihalászott műanyag flakonok újrahasznosítása” programjuk keretében, már több, mint 5 millió pár cipő került forgalomba (Adidas, 2018).

\section{Bolygó}

\section{Partnerek ösztönzése}

Az Adidas egyik legrégebbi partnere évente 110 millió pár cipősarkot készít termoplasztikus (hőre lágyuló) gumiból és polisztirolból (műgyanta). Az alapanyagok árának elmúlt években tapasztalható növekedése miatt, a cég arra kérte beszállítóját, hogy a polisztirol gyártása helyett újrahasznosított polisztirolt próbáljanak meg felhasználni. Ennek érdekében élelmiszerek csomagolóanyagából elő tudták állítani az újrahasznosított mügyantát, melynek köszönhetően évente 1500 tonnával csökkentették a polisztirol gyártását (Adidas, 2013).

1983 óta a Calzaturificio Jumbo stratégia partnere az Adidasnak. Az Adidas kérésére vállalták, hogy napelem rendszert helyezzenek el épületeik tetején. 2014-ben a Jumbo 268,618 kWh elektromos áramot termelt, melynek 90\%-át felhasználták a termelésben. A panelek kiépítése hatalmas összegbe került, mely megtérülési ideje 12 év, azonban a hosszú távú kapcsolat a céggel biztosítékot nyújtott számukra (Adidas, 2014).

Az Adidas kérésére a FENC - Far Eastern New Century - textilgyártó partner is támogatta a szennyvíz újrahasznosítási programot, valamint megpróbálták csök- 
kenteni a festési folyamatoknál felhasznált víz mennyiségét. A vállalat 70 millió liter vizet spórolt meg 1 év alatt azzal, hogy tisztított vizet használt a festési folyamatoknál. A munkavégzés során keletkezett szennyvizet két csoportba osztják: magasan vagy alacsonyan szennyezett víz és különböző medencében tárolják. A kezelési folyamat innentől kezdve eltérően zajlik.

\section{Zöld Vállalat}

A cég 2012-ben vezette be „Zöld Vállalat” programját, mely keretén belül célul tűzték ki, hogy minél szélesebb körben, minél több területen igazolt módon növeljék környezeti teljesítményüket. Első lépésben az irodaházak, a gyártási részleg, majd a logisztikai központok szereztek ISO 14001 tanúsítványt. Európában, Kanadában és az USA-ban is több telephelyük szerezte már meg a tanúsítványt.

Céljaik között szerepel, hogy éves szinten 3\%-kal csökkentsék a $\mathrm{CO}_{2}$ kibocsátás mértékét.

A kiskereskedelmi szektorra kiterjesztett környezetbarát intézkedéseiket HomeCourte néven ismertették. Ez a program az üzletekben egy intelligens irányítási technológia megvalósítását foglalja magába, mely optimalizálni tudja a fütést, hűtést, világítást, az ajtók működtetését. Ezzel a módszerrel 50\% energiát tudnak megspórolni. LED égők, energiahatékony felszerelések tovább segítik a szénkibocsátás csökkentését. A mosdókban érzékelős papír adagolót alkalmaznak, a csapoknál víztakarékos fejeket szereltek fel, a hulladékot pedig szelektíven gyüjtik. 6 hónapos tesztelési idő után elemzik az addig elért eredményeket (Adidas, 2014).

\section{Kemikáliák használata}

Hosszú éveken át a termékek vízlepergető rétegének kialakításához - a Pumához hasonlóan - perfluor-karbont használtak az Adidasnál, ami egy igen szívós, toxikus, le nem bomló vegyület. 2013-ban döntöttek úgy, hogy 100\%-ban felhagynak a kemikália használatával. Ennek érdekében külső szakértők bevonásával igyekeztek olyan helyettesítő anyagot találni, mely alkalmazása nem okoz változást a termék minőségében, használhatóságában, esztétikusságában. 2016 végégig sikerült megvalósítaniuk, hogy az összes forgalomba kerülö termékük 90\%-ban PFC mentes (poliés perfluor-karbon) legyen és számításaik szerint 2019 őszére ez az arány eléri a 99\%ot (Adidas, 2018). A következő veszélyes vegyület, mely csökkentésével foglalkoznak, a szintetikus bőr előállításánál használt dimetil-formamid.

A Nike-hoz és a Puma-hoz hasonló intézkedéseket is tettek e területen. A korábban hatályba lépett szigorítást (Product Restricted Substance List) a veszélyes anyagok használatára vonatkozóan ők is betartják, illetve beszállítóiknak is készítettek egy listát az alkalmazható kemikáliák köréről (Adidas, 2017). 
4. Beszállítók környezeti auditja

2010-ben az Adidas környezetvédelmi felülvizsgálatot rendelt el 24 beszállítójánál. A széleskörü átvilágítás kiterjedt pl.: hulladékok kezelésére, szennyvíz ártalmatlanítására, felszín alatti vizek védelmére, tűzvédelemre, biztonságos munkakörülmény kialakítására. A feltárt eredmények alapján pedig megkérték partnereiket, hogy tegyék meg a szükséges lépéseket. 3 évvel később egy újabb felülvizsgálat következett, mely során egyértelmüen látható volt a fejlődés, a partnerek 75\%-nak javult környezeti mutatója.

\section{Energiafelhasználás}

2020-ig 20\%-os energiacsökkentést várnak beszállítóiktól (partnerek 37\%-a csatlakozott már), saját munkafolyamataiknál pedig komplett épületfelügyeleti rendszer bevezetését célozták meg, mely segíti a legoptimálisabb energiafelhasználás megvalósítását. Az új beruházásoknál - elsősorban a németországi irodáknál - LEED tanúsítványt szeretnének megszerezni a következő években. Moszkvában és Santiagoban átadott irodaházak már megkapták a LEED tanúsítást.

Célul tűzték ki, hogy különböző sportprogramok környezeti lábnyomát is csökkentsék, mely érdekében kézikönyvet dolgoznak ki különböző alternatívák, jó-gyakorlatok bemutatásával (Adidas, 2017).

\section{Következtetések, javaslatok}

Az elmúlt két évtizedben kutatói és sportszakmai körökben is egyre nagyobb teret nyert a sport és a környezetvédelem kapcsolatának vizsgálata, mely terület egyik fontos eleme lehet a sportszer- és sportruházat gyártó vállalatok fenntarthatóságot szolgáló intézkedéseinek vizsgálata.

Az elmúlt években megjelent jelentések, publikációk áttanulmányozásával jól nyomon követhető volt a fejlődés a vállalatok környezetbarát megoldásainak alkalmazása területén. A Nike és az Adidas esetében is elmondható, hogy vállalatok vezetői felismerték, hogy a vállalat egy társadalmi és ökológiai környezetben működő komplex rendszer, ezért célrendszerükbe az erkölcsi alapon nyugvó, kiegészítő célokat is integrálni kell, mint például a természeti környezettel való törődés. Elismerték, hogy tevékenységük igen jelentős környezeti hatással bír. A környezetterhelés csökkentése érdekében növekvő mértékben használnak újrahasznosított alapanyagot, új technológiák bevezetésével mérsékelni tudják a gyártás során szükséges pl.: kemikália, energia szükségletet. Nem csak a saját, hanem partnereik környezettudatos magatartását is javító intézkedéseket vezettek be, külső cégektől kértek segítséget és 
támogatták más szervezetek környezeti/társadalmi felelősségvállalás területén végzett tevékenységét.

A Nike esetében elmondható, hogy az egyes fejezetek rendkívüli részletgazdagsága, és a különböző területekre vonatkozó számszerű adatok segítenek abban, hogy könnyen információt szerezzünk a cég tevékenységéről. Terv-tény adatokkal közölt környezeti intézkedéseik jól átláthatóvá teszik törekvéseiket és az eddig elért eredményeiket. Több, 2020-ig teljesítendő cél került meghatározásra 2015-ben, mely eredményeiről is olvashatunk a jelentésekben.

Az Adidas intézkedései kapcsán megállapítható, hogy elkötelezett a környezetvédelem mellett. A Nike-hoz képest kevesebb számszerű adat állt rendelkezésünkre, azonban a bemutatott intézkedések köre jól szemlélteti felelős magatartásukat.

Összességében elmondható, hogy a fenntarthatóság követelményrendszerének való megfelelésben a sportszektor valamennyi szereplőjének - sportolóknak, egyesületeknek, sportrendezvények szervezőinek, sporthoz köthető gazdasági, társadalmi szervezetek képviselőinek - részt kell vállalnia.

A publikáció elkészítését a GINOP-2.3.2-15-2016-00062 számú projekt támogatta. A projekt az Európai Unió támogatásával, az Európai Regionális Fejlesztési Alap társfinanszírozásával valósult meg.

\section{Hivatkozott források}

[1.] Adidas (2018): Annual Report. Megjelenés: 2019 Letöltés dátuma: 2019. szeptember Forrás: https://report.adidas-group.com/fileadmin/user_upload/ adidas_Annual_Report_GB-2018-EN.pdf

[2.] Adidas (2017): Sustainability Progress Report. Megjelenés: 2018 Letöltés dátuma: 2019. május Forrás: https://www.adidas-group.com/media/filer_public/08/7b/087bf055-d8d1-43e3-8adc-7672f2760d9b/2016_adidas_sustainability_progress_report.pdf

[3.] Adidas (2014): Sustainability Progress Report 2014. Megjelenés: 2015 Letöltés dátuma: 2016. május Forrás: https://www.adidas-group.com/media/ filer_public/e8/32/e832823b-8585-4e26-8990-07b80e3ae71c/2014_sustainability_report_make_a_difference.pdf

[4.] Adidas (2013): Fair Play/Sustainability Progress Report. Megjelenés: 2014 Letöltés dátuma: 2015. március Forrás: http:/www.adidas-group.com/ media/filer_public/2014/04/14/2013_sustainability_progress_report_fair_ play_final_en.pdf 
[5.] Brar, R. S. - Pathak, A. (2016): Sports and environment. SOPAAN-II, Vol. 1 Nr. 1 pp. $7-11$.

[6.] Deng, W. - Zhou, J. (2017): Analysis on Sports and Environmental Protection Problems. Megjelenés: 2017 Letöltés dátuma: 2019. február Forrás: http://dpi-proceedings.com/index.php/dteees/article/viewFile/7859/7435

[7.] Elks, J. (2013): Nike, Inc. Unveils ColorDry Technology and Facility That Eliminate Water, Chemicals In Dyeing, Megjelenés: 2013 Letöltés dátuma: 2015. július Forrás: http://www.sustainablebrands.com/news_and_views/ clean_tech/jennifer-elks/nike-inc-unveils-colordry-technology-facility-eliminate-wate

[8.] Internet 1: Nike or Adidas? Which one is more sustainable? Megjelenés: 2017 Letöltés dátuma: 2019. szeptember Forrás: https:/www.trustedclothes.com/blog/2017/06/01/nike-adidas-one-sustainable/

[9.] Giulianotti, R. - Darnell, S. - Collison, H. - Howe, P.D. (2018): Sport for development and peace and the environment: The case for policy, practice, and research. Sustainability, Vol. 10 Nr. 7, pp. 2241.

[10.] Liam, C. (2015): Adidas release stunning new limited edition all white No Dye Pack football boots. Mirror. Megjelenés: 2015 Letöltés dátuma: 2019. április Forrás: https:/www.mirror.co.uk/sport/football/news/adidas-release-stunning-new-limited-5636911

[11.] Moghaddam, K. S. - Abadi, B. H. - Eydi, H. (2018): Investigating Environmental Responsibilities Involved in Sport Organizations. International Journal of Sports Science, Vol. 8 Nr. 4, pp. 109-117.

[12.] Nike, Inc. (2019): Purpose Moves Us-FY18 Impact Report. Megjelenés: 2019 Letöltés dátuma: 2019. szeptember Forrás: https://s3-us-west-2.amazonaws. com/purpose-cms-production01/wp-content/uploads/2019/05/20194957/ FY18_Nike_Impact-Report_Final.pdf

[13.] Nike, Inc. (2018): Maximum Performance, Minimum Impact - Sustainable Business Performance Megjelenés: 2018 Letöltés dátuma: 2019. február Forrás: https://sbi-prd-s3-mediabucket.s3.amazonaws.com/wpcontent/uploads/2018/05/18175102/NIKE-FY1617-Sustainable-Business-Report_FINAL.pdf.

[14.] Nike, Inc. (2013): Sustainable Business Performance Summary Megjelenés: 2014 Letöltés dátuma: 2015. július Forrás: http://www.nikeresponsibility. com/report/uploads/files/FY12-13_NIKE_Inc_CR_Report.pdf 
[15.] Ráthonyi-Ódor K. (2015): Sportökológia. Debreceni Egyetem. Campus Kiadó. 121.o.

[16.] Shiply, M. (2018): Sport and environment. Megjelenés: 2018 Letöltés dátuma: 2019. február Forrás: https://www.progressiveteacher.in/sport-and-environment/ Letöltés dátuma: 2019. február

[17.] Tóthné Szita K. - Roncz J. (2016): Veszélyben a környezet! Megoldások keresése az energetika és biotechnológia területén. In: Tóth A.Né - S. Gubik A. (szerk.) (2016): Magyarország 2025-ben és kitekintés 2050-re. Tanulmánykötet. Budapest, Arisztotelész Kiadó, pp. 275-287.

[18.] Trendafilova, S. - McCullough, B. - Pfahl, M. - Nguyen, S.N. - Casper J. - Picariello, M. (2014): Environmental sustainability in sport: Current state and future trends, Global Journal on Advances in Pure \& Applied Sciences. Vol. 3, pp. 9-14.

\section{Szerzők:}

\section{Dr. Ráthonyi-Odor Kinga, PhD}

adjunktus

Debreceni Egyetem Gazdaságtudományi Kar Sportgazdasági és -menedzsment Tanszék rathonyi-odor.kinga@econ.unideb.hu

Prof. Bácsné Prof. Bába Éva

Debreceni Egyetem Gazdaságtudományi Kar Sportgazdasági és -menedzsment Tanszék egyetemi tanár

\section{bacsne.baba.eva@econ.unideb.hu}

\section{Dr. Ráthonyi Gergely, PhD}

adjunktus

Debreceni Egyetem Gazdaságtudományi Kar Alkalmazott Informatika és Logisztika Intézet rathonyi.gergely@econ.unideb.hu 